\title{
Methodological Experiences in Collaborative Ethnography. Communication and Participation as Frameworks for Constructing in Common
}

\author{
Aurora Álvarez Veinguer \\ Granada University, Spain \\ Rocío García Soto \\ Granada University, Spain
}

\author{
Antonia Olmos Alcaraz \\ Granada University, Spain
}

DOI: https://doi.org/10.18778/1733-8077.18.1.01

\section{Keywords: \\ Collaborative \\ Ethnography; Stop \\ Evictions Granada \\ 15M; Housing; \\ Methodology; Debate \\ Groups}

\begin{abstract}
In this article, we will analyze how we built the research process of a collaborative ethnography with the Stop Evictions Granada 15M Movement (SEG15M). We will begin with a brief contextualization of the housing issues in Spain and the SEG15M movement to explain why we started the co-research experience with the movement. Next, we will clarify the composition, function, and main purposes of the 'debate groups' in our research, as well as their particular differences and dynamics concerning other qualitative techniques. Finally, we will focus on two main aspects, participation and communication, which emerged within the debates and later materialized into a transmedia project and the development of a radio soap opera. The latter is a product, and a process, of collaborative work that bridges communication and participation at the intra- and inter-group levels. It is a fictional story that emerges from the common lived experiences of the groups.
\end{abstract}

Aurora Álvarez Veinguer is an Associate Professor of Social Anthropology at Granada University, Spain. Her main research interests are identity construction, migration processes, collaborative ethnography, and participatory methodologies. Some of her recent publications are: Álvarez Veinguer Aurora, Arribas Lozano Alberto, and Dietz Gunther. 2020. Investigaciones en movimiento: etnografías colaborativas, feministas y decoloniales [Research in Motion: Collaborative, 
Feminist, and Decolonial Ethnographies]. Buenos Aires: CLACSO and the article Álvarez Veinguer, Aurora and Luca Sebastiani. 2020. “Habitar la investigación en la universidad neoliberal y eurocentrada: la etnografía colaborativa como apuesta por lo común y la subjetivación política [Inhabiting Research in the Neoliberal and Eurocentric University: Collaborative Ethnography as a Commitment to the Common and Political Subjectivation]." AIBR, Revista Iberoamericana de Antropología 15(2):247-271.

email address: auroraav@ugr.es

Rocío García Soto received her Ph.D. in Social Anthropology from the University of Granada, Spain. Her main research interests are related to housing, ethnographic methodologies, and social movements. Some of her recent publications are: García Soto, Rocío. 2020a. “Dentro/fuera y posiciones de frontera. Transgrediendo límites entre análisis y acción desde una investigación activista con la plataforma de afectados por la hipoteca de Barcelona [Inside/Outside and Border Positions. Transgressing Limits between Analysis and Action from an Activist Investigation with the Platform for Those Affected by the Barcelona Mortgage]." Empiria 48:15-38. García Soto, Rocío. 2020b. “Qué pasa cuando dejamos de observar y nos ponemos a participar? Reflexiones entorno a la 'observación participante' desde una investigación comprometida [What Happens When We Stop Ob- serving and Start Participating? Reflections on 'Participant Observation' from a Committed Investigation]." Pp. 385-410 in Investigaciones en movimiento. Etnografías colaborativas, feministas y decoloniales [Research in Motion: Collaborative, Feminist, and Decolonial Ethnographies], edited by A. Álvarez Veinguer, A. Arribas, and G. Dietz. Buenos Aires: CLACSO. email address: rogarso@ugr.es

Antonia Olmos Alcaraz is an Associate Professor of Social Anthropology at Granada University, Spain. Her main research interests are related to the otherness / identity process, racism and immigration, social and mass media, and ethnographic methodologies. Some of her recent publications are: Cota, Ariana S. and Antonia Olmos Alcaraz. 2020. "Sisters, Partners, or Something More? Collaborative Path Together with Stop Evictions." AIBR, Revista de Antropología Iberoamericana 15(2):1-19; Politzer, Malia and Antonia Olmos Alcaraz. 2020. “Covert Islamophobia: An Analysis of the New York Times and The Wall Street Journal Headlines before and after Charlie Hebdo." Comunicación y Sociedad e7601:1-24; Padilla, Beatriz, Joana Azevedo, and Antonia Olmos Alcaraz. 2015. "Superdiversity and Conviviality: Exploring Frameworks for Doing Ethnography in Southern European Intercultural Cities." Ethnic and Racial Studies 38(4):621-635.

email address: antonia@ugr.es

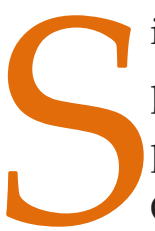

ince the 1970s, it is possible to identify profound discussions about the ways of producing knowledge in social sciences. Questions such as the relationship between researchers and the subjects of study, the forms of engagement with specific research situations, or the positions of those involved have been at the center of the debate. Collaborative research (Lassiter 2005; Leyva and Speed 2008; Álvarez Veinguer and Sebastiani 2020), the perspective that underpins the content of this article, is constituted in the heat of these epistemic proposals-participatory action research (Fals Borda 1986; Villasante 2007), feminist epistemologies (Harding 1993; Gregorio 2019), activist-militant research (Malo 2004; Hale 2008; Greenwood 2008), or epistemologies of the South (Santos 2019). Such proposals share the need to abandon the extractive principles of certain social research (Grosfoguel 2016). Collaboration, in this theoretical-methodological proposal, has to do with the fact that the 
entire research process-the research design, data production, interpretation, and analysis-is carried out together with the people involved in the research. Introducing the condition of co-labor or co-research implies: i) transforming the relationship between the research subject and the researched object (Holmes and Marcus 2008); ii) transforming the status of the 'field' where data collection took place within a space of co-conceptualization (Vasco 2002; Rappaport 2007); and iii) transforming the classic separation between theory and practice (Köhler 2018; Leyva 2018), among others.

\section{How Did We Construct the 'Whats' in a Collaborative Ethnography?}

We start this article with an epistemological justification for our research process, which was based on our desire to distance ourselves from the extractive ways of conducting traditional research. We did not want to investigate 'about' but rather 'with' to get to our findings. For this, we had to adopt co-analysis as our main perspective.

If we think about the 'hows' of conventional research, or how one is proposed, the initial formative phase is where one defines the 'whats' or research questions and objectives. This is usually the 'desk work' process (Velasco and Diaz de Rada 2006), carried out by an individual or a group of researchers. Some social scientists consider this phase as 'pre-research.' However, this is very debatable due to the epistemological starting points that underlie any research process, referring to the necessities of answering the 'whys' and 'for what' of the research. These cannot be separated from the 'whats' of the methodological framework that any proposal will be built upon. A segment of the so-called desk work is what is known as research design, implying the development of an outline where the objectives are defined and research points are addressed. All the while indicating and justifying the social situations that the researcher wants to investigate, which actors to contact, which places to visit, and what methodologies and techniques to carry out, anticipating the chronology and scheduling of the research. In most cases, desk work is defined as the steps of formulating the objectives and the subject being investigated, and consequently-the 'how.' These are the tasks assigned and assumed by the conducting researcher(s). It is this precise first step of defining the 'whats' or research questions that we have collectively internalized to question and uncover from its inception, certain extractivist practices that are deeply rooted in more traditional research (Grosfoguel 2016; Santos 2019; Álvarez Veinguer and Sebastiani 2020). Too often in a decontextualized manner and without connections or relations with the desired communities or collectives (even after answering crucial or relevant queries), researchers are distant from the realities, wishes, and necessities of the groups they wish to research. ${ }^{1}$ Throughout our research project with Stop Evictions Granada 15M (SEG15M), a movement located in the city of Granada (Andalusia, Spain) that struggles for the right to proper housing conditions, we put in place certain mechanism of active listening that materialized into what we call 'debate groups.' ${ }^{2}$ Its objective was to

\footnotetext{
${ }^{1}$ We are differentiating between research done 'on' or 'over' a movement, group, or community and one conducted 'alongside' or 'with.'

${ }^{2}$ Project: "Emerging processes and communal agencies: the praxis of collaborative social research and new forms of political subjectivation" (I+D+I, State Program for the Promotion of Scientific and Technical Research of Excellence, Ministry of Economy and Competitiveness of the Spanish Government). Reference: CSO2014-56960-P. The project was finalized in December 2018 and was based on different case studies developed from academic centers in Granada, Barcelona, New York, and Veracruz. Regarding the Granada team, although there were only three people who signed the text, it is sustained by a collective process. The rest of the work team is made up of Ariana
} 
bring into dialogue the common lived experiences and acknowledge the individual narratives of the collective that everyone was a part of. ${ }^{3}$ However, at no time did we present pre-formulated objectives or preconceived analytical notions. The intention (our methodological objective) was to activate various intersubjective spaces where we wagered on the 'encounter' to start the framing of the 'whats' of the research ${ }^{4}$ (Álvarez Veinguer and Olmos Alcaraz 2020). Likewise, it was not the initial objective of the aforementioned 'debate groups' to conduct an exclusive ex-post analysis on behalf of the researchers of the content being formulated in the groups. Furthermore, and at every turn, we strove to evade the act of speaking 'on behalf' or 'for' other analysis that emerged in the groups. Instead, we focused on how people narrated their stories and experiences. We believed that in the realm of possibility, co-analysis would articulate the 'hows' of the research (Vasco 2002; Rappaport 2007; 2008; Bertely 2018; Köhler 2018).

Sánchez Cota, Luca Sebastiani, and many colleagues from Stop Desahucios Granada-15M (SEG15M).

${ }^{3}$ The implementation of this experience stems from a previous link between research and activism. In November 2015, we approached two SEG15M neighborhood assemblies, including the one in Zaidín. In both cases, we expressed our research intentions, as well as our commitment to solidarity and support for their struggles. Throughout this time, the research tools deployed in each assembly have been different, as they were adopted to the characteristics of each space. Similarly, our role as committed researchers has been heterogeneous. Some played a more 'activist' role, taking on the day-to-day tasks of the collective, as opposed to those who played a more peripheral role in these issues. It is important to underline that some researchers had previous links and relationships with SEG15M that started before this specific project.

${ }^{4}$ By this we do not mean that there were no prior objectives or interests on the part of the researchers. In fact, as we have argued in other works (Álvarez Veinguer at al. 2016; Sánchez et al. 2017; Olmos Alcaraz at al. 2018), building collaborative research does not mean accepting just anything, but rather that a collective negotiation process must necessarily be developed with all the people involved in the research. For us, collaboration meant developing knowledge-building experiences that were based on dialogical and horizontal principles.
In summary, the 'debate groups' wanted to operate as (1) a space to listen and be heard (something that many people sadly did not have the time due to their everyday life emergencies) and (2) as a means to collectively construct the research and not simply produce an analysis of the group discussions.

In our research, we wanted to approximate a process of daily arrangements and political subjectivation. It was after the 'collective self-diagnoses' exercises, ${ }^{5}$ throughout 16 'debate groups' held, that participation and communication emerged as two transversal axes that the group considered as not being taken care of within the movement and seemed important to focus on them. In reiterated fashion, two concerns worried people especially-on the one hand, how SEG15M was represented and how it communicated with society at large; and on the other, how to increase the level of engagement and involvement among assembly attendees. Collectively, we began to work on both points.

This article aims to present how we constructed the research process of collaborative research alongside SEG15M. For this, we shall briefly contextualize the housing issues in Spain and the emergence of SEG15M, collective fighting for the right to housing. We shall momentarily go over the assembly procedures of the movement, and in the subsequent section, we will explain the composition and concerns of the various 'debate groups' in our research. We will also analyze the 'hows' of these groups and their traits and characteristics. In the following section, we will inspect the aforementioned focal points of participation and communication that emerged as the key points to focus and work on in

\footnotetext{
${ }^{5}$ Participation Action Research (PAR) classifies the first phase of any research as the fulfillment of a diagnosis.
} 
the subsequent phases of the research, which later materialized into a transmedia project and a radio soap opera.

\section{SEG15M and the Struggle for the Right to Housing}

The outbreak of the global financial crisis (20072008) had a devastating impact on the Spanish economy. The more prominent consequences were the increase in poverty and unemployment, resulting in the insolvency of thousands of citizens and the immediate increase in evictions. By and large, this was the outcome of five decades of speculation on the Spanish economy and the real estate market. ${ }^{6}$ As Harvey and Smith (2005) point out, there was a shift in the circulation of capital: from industrial production to the construction market.

It is estimated that between 2008-2019 there were more than 1,000,000 evictions. ${ }^{7}$ In the first years of the crisis, evictions were caused by foreclosures. However, the data for 2019 reveal that evictions

\footnotetext{
${ }^{6}$ With the creation of the Ministry of Housing in 1957, housing policies were aimed at purchasing and retaining private properties. As the minister José Luis de Arrese affirmed, it was to turn Spain into a country of owners and not proletarians. Along with the approval of the Spanish Constitution commenced: i) the privatization of the banking sector, ii) the entry into the European Union, and iii) the accession to the Eurozone. These generated a massive influx of foreign investment, returning the Spanish economy to the global market. To this would be added the period of 1996-2007, where the then Spanish governments deregulated the housing market, passing laws that loosen rents, facilitating the requalification and accessibility of land outside Municipal Plans and promoting urban megaprojects (Naredo and Montiel 2010; Gaja 2015). Moreover, with the entry into the Eurozone, and once the currency stabilized, the real estate sector needed to increase the volume of its business to maintain its profits. Office branches were opened across the country, and the minimum solvency criteria for granting mortgage loans was relaxed (Colau and Alemany 2012; Suárez 2014).

${ }^{7}$ For detailed information, see: https://afectadosporlahipoteca. com/2020/01/28/desde-2008-se-han-producido-1-002-000-desahucios/.
}

numbered $68 \%$ and were due to rent not being paid (CGPJ 2019; PAH 2019). Andalusia, a region in the south of Spain, where Granada is located, is second to Catalonia in the most affected area for evictions. In 2019, there were 8,806 evictions (CGPJ 2019). This would indicate an average of 25 evictions daily (APDHA 2019). For the city of Granada, in the same year, there were 1,078 evictions, of which 360 were foreclosures and 651 for non-payment of rent, juxtaposed with a socio-demographic context where the unemployment rate was $21.19 \%$, and the at-riskof-poverty population was 35\% (INE 2019).

This social-economic backdrop fueled the creation of SEG15M. ${ }^{8}$ The collective was formed from the synergies of the platform for People Affected by Mortgages (PAH) and the $15 \mathrm{M}$ movement. It was in the assembly of May 22, in which a charting document was approved and paved the way for the creation of the collective. It asserted "an innate right to housing as a social good over an economical one" (AA.VV. 2016:30 [trans. AAV, RGS, and AOA]). By the end of the year, SEG15M achieved its first victory of an in-lieu-of-payment for an affected individual. By the end of the first year of existence, 70 families had appealed to the group and 14 evictions had been stopped (AA.VV. 2016:14). At the time of writing, the group had 11 committees in various neighborhoods and towns in the Granada region of Andalusia. It is modularly structured with different groups for work, training, and coordination. Its principal tool is the assembly, where cases are reviewed collectively, and two types of demonstra-

\footnotetext{
${ }^{8}$ It should be noted that both SEG15M and the People Affected by the Mortgage Platform (PAH) were not unprecedented. Their origins go back to past movements like the 'Movement for Dignified Housing' (2003) or 'V for Housing' (2006). Given the length limitations of this paper, for more information, we recommend the works of: Álvarez, Zapata, and Zapata (2014); Colau and Alemany (2012; 2013); Mangot (2013a; 2013b); Mir et al. (2013); Sebastiani, Fernandez, and García (2016).
} 
tive actions that are invoked at either the bank's branch door or the eviction house, where they halt the expulsion.

Having briefly summarized the financial crisis of 2007 and the socio-economic backdrop where our research takes place, with its ongoing housing predicament that led to the creation of SEG15M, we will next analyze the methodological approach, focusing on one of the techniques used in our work.

\section{The ‘Debate Groups': Composition and Function}

To further our methodological approach, which, in this case, we are denoting as a 'debate group,' we will note the methodological basis that guided our design. We shall then reflect on both the continuities and the particularities while maintaining the epistemic position of collaborative ethnography (Rappaport 2007; 2008; Dietz and Álvarez Veinguer 2014; Álvarez Veinguer and Olmos Alcaraz 2020; Álvarez Veinguer and Sebastiani 2020) that pushed us in the way it has.

\section{Methodological Bases: The Birth and Development of 'Debate Groups'}

Our 'debate groups' were based on the qualitative research technique of Group Discussion. ${ }^{9}$ This investigative social technique, which is qualitative in nature, evolves in our context from the works of Jesus Ibáñez (1979). He refers to group discussions as "places of conversation, where to converse reveals a symbolic elaboration of a collective task, as

${ }^{9}$ A comparative analysis between the techniques of the Discussion Group and the Focus Group can be seen with our proposal of Debate Groups in Álvarez Veinguer and Olmos Alcaraz (2020). well as adhering to it, psychologically and socially" (Domínguez and Dávila 2008:98 [trans. AAV, RGS, and AOA]). The conversation aspect, as we shall see, became central to our methodological procedure. It seemed fundamental to activate methodological tools that would promote group dynamics, dialogue, and a non-hierarchical structure of exchange of knowledge (Olmos Alcaraz et al. 2018).

We held 16 'debate groups' with three different groups, each session lasting approximately two hours. Some were composed of five people, while others by seven. The sessions were recorded, with the shared needs, concerns, and proposals noted in edited documents that would later be distributed in the fifth and final session. These papers incorporated changes, suggestions, and further proposals that were taken up by the assemblies. On occasions, the groups were fewer than those outlined, something which would not be considered accurate by some methodological approaches similar to our own. However, the lack of time, and the difficulty of doing something as mundane as assisting a session with people who have vulnerable existences and are beset by everyday emergencies, influenced the number of attendees in each session. The groups were designed for either five or seven people, but at times they were three or four. For us, however, this was not a problem. On the contrary, it allowed us to experience sessions where the atmosphere was 'closer' and more intimate, with wider opinions and life stories, which, as we understand it, gave further richness and depth to our practices. A lot of trust was generated and even though some individuals missed a session, they were easily incorporated in the following one without any difficulty. Like group attendance, the duration of sessions varied. There were days the meetings started 30 or 40 minutes later than planned (due to waiting 
for two or three individuals) or ended an hour later because individuals were still conferring.

The 'selection' process for establishing the groups fell outside the criteria of the self-representing groups discussions (Ibáñez 1979). For us, it was important to take into account: (1) the affinity of group members, not bringing together those who did not 'mesh' well; (2) everyone knowing each other; and (3) sufficient diversity to match people at different stages of their housing issues, gender balance, experiences, et cetera. Ultimately, we followed the criteria to help people feel comfortable enough to express themselves and speak freely. Our aim was not to "create data, but rather construct processes-relationships-connections"10 (Álvarez Veinguer and Olmos Alcaraz 2020:124 [trans. AAV, RGS, and AOA]).

Each group used to meet once a week at The Ribera. ${ }^{11}$ The selection of this place was purposely done because it was a familiar and comfortable space where the weekly Stop Evictions assemblies for the Zaidín neighborhood of Granada met. We sought to avoid alleged 'neutrality' or formal settings for pleasant and familiar ones for the participants, places where comfort and familiarity superseded the cold unknown.

In our 'debate groups' there were no expert figure moderators, researchers, nor anyone in charge of eliciting people to speak. Instead, we participated

\footnotetext{
${ }^{10}$ As explained, the profiles were very varied. The first group (group A) was made up of seven people, three men and four women aged between 30 and 70 . Group B consisted of five people, three women and two men aged between 40 and 50. Group $\mathrm{C}$ consisted of six people, two men and four women aged between 30 and 45 .

${ }^{11}$ The 'Local de la Ribera' is an associational space that began in May 2011. It is located in the popular neighborhood of Zaidín (Granada). It houses various social projects, among which is SEG15M. See: https://colectivolaribera.es/tag/local-de-la-ribera/.
}

in the debates when we considered we had something to contribute. In other words, the programmatic idea of staying "on the sidelines" during the conversations was incongruous for us, even though we understood what the functional responsibilities were of group dynamics (Ibáñez 1979). As investigators, we were part of the group. In this sense, "more than dialoguing, we strove to listen and to make ourselves be heard as a group" (Álvarez Veinguer and Olmos Alcaraz 2020:122 [trans. AAV, RGS, and AOA]). All the while aiming for moderation as accompaniment instead of supervision, we stressed our non-expert status.

In the sessions, we worked on different topics. Although we initially prepared the topic themes for the first meeting, all subsequent sessions were built upon the expressed worries and concerns that would emerge in the debates respectively; from one week to the next. The first session, the one we designed, and to an extent conducted, had two objectives: (a) to know the shared stories about SEG15M from the last five years, and (b) to know the shared stories about its accomplishments. These objectives were worked through across three questions: (1) What are the first memories of SEG15M that you have? (2) Why and how did you get involved with SEG15M and why do you continue your involvement? and finally, (3) What moments do you think are more important in your history as a movement and as a group? We also established session guidelines that were unanimously agreed upon by the group. We agreed to follow the procedural guidelines for all meetings, which were broadly displayed at all times and meetings. The guidelines were as follows: (1) to not lose sight of the objective of debating, analysis, and reflecting about our discussions and practices to strengthen the group; (2) to share relevant firsthand experiences in one's voice and a respectful 
manner, keeping in mind that there might be other perspectives; (3) to mute all electronic devices and avoid entering-exiting or doing so without bothering others; finally, (4) to feel as comfortable as possible to share one's opinion and listen to one another. The worked topics in the following sessions allowed us to collectively reflect on the meaning and implications of the organization (of a movement) to be a collective, as well as the work completed and what is yet to be done by the group to achieve such. Furthermore, how to take care and engage the people in the movement and aspects relating to the intra-communication between participants, within the movement, and other social agents.

In the sessions, we focused on dialoguing and co-analyzing the emerging questions, attempting to co-interpret the meanings of the covered topics and problems. For the preparation of this last part of the work, we systematically organized all the discussed narrations and shared them in an easy-to-read format to socialize the discussion. This allowed for the debate participants to review and thoroughly acknowledge the material constructed by their group, leading to the final session.

\section{Methodological Proposal: Potentiality and Innovations}

If we were to highlight something from our methodological model concerning the 'debate groups,' it would be, without a doubt, its potentiality to generate listening and co-analysis spaces for the collective. Co-analysis implies "placing the participants' thoughts in a parallel analysis, instead of considering them as simply ethnographic data" (Rappaport 2007:202 [trans. AAV, RGS, and AOA]). Therein lies the value in our approach, which allows us, among others, to access "new conceptual tools to there- by give meaning to realities" (Rappaport 2007:200 [trans. AAV, RGS, and AOA]) in which to do our research. An example of this is how the sessions were named 'debate groups.' As we write these words, with a social science background and inevitably a professional particularity, we initially believed in implementing the group discussion technique at the start of our project with perhaps some particularities. However, it was the group that decided to name itself a 'debate group' and not a 'discussion.' It was not a simple word change without any other epistemological implications. Rather, it was aform of more precisely identifying and keeping by the group's sentiment of "what we were doing there and why." In other words, with the simple act of self-identifying, "the implicit theory [that is always present] in political practices" (Köhler 2018:411 [trans. AAV, RGS, and AOA]) was evidenced. We were able to see that one of the core elements of the group was to construct (more so than 'discuss') from dialogues and debates. On the other hand, 'debate groups' emerged as examples of spaces for constructing meaning from collective shared experiences. Through questioning, listening, and the conversational potential, we reached various collective assents, beyond compromises that allowed us to further construct meaning via co-analyses. As a collective task of the symbolic elaboration (Domínguez and Dávila 2008), it generated synergies that went beyond the sum of its parts. It was here where the reflexive, analytical, and interpretive capacity is evidenced, of and for the group. It exceeds the bounds of the "inside/outside" assertion, intricating rather than simplifying the dynamic and heterogeneous reality (Rappaport 2007). With the 'debate groups' we incorporated listening through conversation, without restrictions or urgency of our hectic schedules, or scheduled assembly work. More importantly, through this technique, we activated processes 
of 'de-authorization' towards the work identified as 'expert' in the social sciences (Álvarez Veinguer and Olmos Alcaraz 2020), which served to start processes of 'authorization' by the Stop Eviction members. By this, we are not referring to disappearing or denying our knowledge, but to 'decentering' ourselves (Arribas 2015). In other words, attempting to place our knowledge at the same level as the knowledge constructed by the rest of the people, as well as recognizing and valuing any proposal that arose in the groups. This caused a certain loss in the control of the process, but we understood that even with the inherent uncertainty, this technique would potentially afford us access to experiences that otherwise would not be possible, opening a possible co-analysis window.

Collaborative work strains the production and validation of knowledge mechanisms since it questions the dichotomies of objectivity-subjectivity and theory-practice, among others (Lassiter 2004; Rappaport 2007; Dietz and Álvarez Veinguer 2014; Arribas 2015; Leyva 2018). ${ }^{12}$ We experienced this in our 'debate groups' in two concrete ways. On the one hand, because we eliminated the category of the informant, we did not see the subjects of the research as those providing inherent information to the expert for it to then be analyzed. Instead, they were subjects that together and with whom we reflected collectively. On the other hand, it was because we also abandoned the idea that only the expert investigator was capable of having and generating valid knowl-

\footnotetext{
${ }^{12}$ Practice, from the most traditional research, is conceived as a set of material activities (far from the theory), or as purely individual actions. This conception of practice, as Vasco (2002:3 [trans. AAV, RGS, and AOA]) states, entails that "a specific territorial space is constructed for ethnographic research, designating a particular space for the practice and another for the theory," and not just a territorial space but a temporality as well-first the world of the subject matters and then that of the researcher and subject of knowledge.
}

edge. ${ }^{13}$ In this way, when the informant category stops making sense, and we begin to understand the subjects as epistemic colleagues (Holmes and Marcus 2008:84), the spaces of fieldwork transform into spaces of encounter and "reflexive dialoguing" (Arribas 2015:61). In this way, the "epistemological status of the fieldwork" (Vasco 2002:3 [trans. AAV, RGS, and AOA]) is restructured. We no longer have to go to the 'field' to collect data, but rather, we are in the 'field' to meet and build knowledge through co-analysis. ${ }^{14}$ The 'group debate' experience should not be just a mere participatory diagnostic. They were processes of concerted active listening to collectively build the research. These were not established as a concrete 'action plan' beforehand, but rather were derivatives of the shared process. We shall narrate this last point in the following section, focusing on our collective reflections and how these have framed the possibility of continuing to co-investigate.

\section{The ‘Debate Groups' Content: Designing the 'Whats' of the Research}

The content of the 'debate groups' was built according to the emerging themes that were identified as necessary in each session. Among various questions, our guiding compass was always pointing at the collective uniting us, SEG15M. As it appears in

\footnotetext{
${ }^{13}$ Assuming consequently that the processes of knowledge validation are based on the division between knowing and feeling, between what is knowledge and experience. As Suárez-Krabbe (2011:192 [trans. AAV, RGS, and AOA]) maintains, "borders that define the field of interaction differentiate what is relevant and irrelevant in scientific research; what establishes knowledge or non-knowledge."

${ }^{14}$ We defined co-theorization as "the collective production of conceptual vehicles that are based on both a theoretical anthropological concept and on concepts developed by our interlocutors" (Rappaport 2008:5). Thus, we prefer to speak of co-analysis because during the debate groups, we analyzed and reflected critically on various topics related to the SEG15M, but we did not construct theoretical meaning or abstract thought.
} 
the charter document, SEG15M is an assembly-led movement that promotes collective decision making, diffusion of information, and the sharing of tasks and responsibilities-to fight for dignified housing for everyone. From this, the act of participating (acting together before others with the same level of engagement) and communicating (sharing information with others) emerged in the debate groups as fundamental actions for SEG15M to remain operational. These two points needed ongoing consideration to improve the collective's function. Beyond these, other questions appeared. The first meetings focused more on personal aspects, where the memories about the initial encounters within the collective took center stage. The 'debate groups' members had joined the collective from very different walks of life and at different times. Some had been members for over a year, while others had been part of the collective since its inception. At this point, we paused to reflect on more formal group questions, where the assemblies and their functions took on more prominence. Some included: improving the time management; working on inclusive participation; rethinking the moderation function of the assemblies; conducting thematic assemblies; working on the assembly's ambiance; or active listening. On the other hand, we emphasized the need to pay more attention to collective emotional support. An example of this would be advocating a noblame atmosphere for new arrivals of the collective. We agreed that all of these should be carried out and placed at the heart of SEG15M; specifically, to work on active listening, empathizing more with new arrivals, and interpreting internal complaints as 'suggestions' rather than 'demands.' In the next section, we will focus on each of these key points (to participate and to communicate) as central questions for the 'debate groups'; also, we will expand on how working on them led to the advancement of the 'whats' of the research materializing into different audio and visual products, and the development of the soap opera.

\section{Participate: Creating in Common}

In the 'debate groups,' we shared that one of the readings that housing movements have been able to elaborate-including SEG15M-is that change will only be possible if many people get involved. Therefore, to obtain results, broader and more active participation must be counted on. However, what did it mean to participate in a collective like SEG15M? The struggle for the right to housing has reconfigured social movements: people are organizing around concrete issues and not ideologies. Traditionally, Spanish housing movements were composed of youths with unstable wages, or jobs, who organized to emancipate from their familial homes. In the case of SEG15M, however, it was mostly composed of "families affected by mortgage foreclosure proceedings" (Colau and Alemany 2012:193 [trans. AAV, RGS, and AOA]). This was a new scenario where it was vital to think of strategies for "incorporating those who do not enter the model of an available, educated, and digitally connected activist" (Marin 2015:1 [trans. AAV, RGS, and AOA]). These being "normal, modest, and of the street people" (Mangot 2013a:78 [trans. AAV, RGS, and AOA]). We agreed that the collective housed individuals from distinct backgrounds, many of which never had previous experiences participating in a socio-political event, "we opened our own eyes" (Group C, Session 1). ${ }^{15}$

This heterogeneity makes SEG15M widely diverse, and one of its virtues is that it offered people a space

${ }_{15}$ To facilitate citation, we separated the sessions into three groups (A, B, C) of four sessions each. 
to "articulate their struggle and grow as an activist, empowering themselves and going from victim to affected, and affected to activist" (Adel, Lara, and Mármol 2014:14 [trans. AAV, RGS, and AOA]). A transformation that implies breaking from deep-seated notions and signaling that not only a change in the way of proceeding is taking place but also a transformation of subjectivity: "I now feel like a different person" (Group A, Session 1). We conceded that actively participating in collective and democratic decision-making processes caused measurable results in people's daily lives. It caused "a shift in focus in regards to the political process; going from being considered as a distant and unalterable reality to being a set of actions and reactions on which it is possible to exert decisive influence" (Adel et al. 2014:14 [trans. AAV, RGS, and AOA]). For this, we pointed out, the collective needed to make people see beyond their cases and participate in the political process:

People come to our group after receiving a tremendous blow... and we, as a group, have to build. And to build is that when someone arrives at the group, the thing to do, as a priority task, is to show them that the group will not solve their case. The group is working for the right to dignified housing; solving their case is but a step in the journey. However, let us be clear, [fixing cases] is not the objective. [Group B, session 4]

One of the most recurring issues at the assemblies is for the collective to make clear that it is not a non-governmental organization (NGO) and does not provide a social aid program. That is, that SEG15M is not a traditional advisory service where a person can relate their problem to a more knowledgeable person and then wait for it to be resolved. Instead, it means that all need to fight together to achieve results. Moreover, the collective's bylaws clarify: "those individuals who participate in counseling and have working legal knowledge (lawyers, jurists, etc.), should share their knowledge in the assembly while avoiding the role of experts, making it clear that everyone's involvement is necessary to reach a solution" (SEG15M 2014 [trans. AAV, RGS, and $\mathrm{AOA}]$ ). As previously stated, the collectively shared advice was one of the main characteristics of this social movement. In fact, "it has proven to be an essential and transformative tool that helps those affected to confront a problem that normally overwhelms them, while concurrently, losing the fear, shame, and feelings of failure associated with the process" (Colau and Alemany 2012:99 [trans. AAV, RGS, and AOA]). During the 'debate groups' sessions, these techniques also allowed us to: (1) create a safe and secure space, (2) socialize tools and knowledge, and (3) be active participants. That is to say, going from being a victim, assisted by an expert, to "becoming an active transmitting agent of knowledge" (Colau and Alemany 2012:100 [trans. AAV, RGS, and AOA]). Many times, this change can be difficult to adopt for it means breaking from deeply ingrained notions and biases. It is also a long molding process where some individuals do not understand how the collective works and leave in frustration. "Some people have come to [SEG15M] and left without grasping the movement. Of course, in one assembly, you cannot get the direction to this, you have to come [much] more" (Group A, session 1). This misunderstanding aspect, we contended, was due to the very nature of the movement, which at times contradicted people's long-held beliefs. "There are people who come off the couch, obeying the boss and never questioning anything; breaking with that hierarchical discipline is not from one day to the next" (Group A, session 1). Notwithstanding, not everyone leaves: "The few people I know who have been catching the direction of this have done 
so because of that collective learning of knowing, being able, deciding what to do, and to debate has been an education, done little by little, in a you-toyou or you-with-another dialogue" (Group A, session 2).

The collective works as both a space for mutual aid meetings and as a politicization learning in which anyone can help or be helped. In some 'debate group' sessions, we remembered how at the beginning of the collective, none of the members knew about mortgages or how to negotiate with financial institutions. "It was there that we realized that if you learn tools, learn knowledge, and you're collectively together with people, you can achieve many things. Those first examples were very valuable to continue" (Group A, session 1). For this reason, one of SEG15M's objectives was to obtain broader and deeper participation of those who pass through it. "Big or small, everything is useful" (Group C, session 2).

Participation was necessary not only of those who were able to and could dedicate a lot of time but also of those who did not. It was here where a question of how to improve the collective surfaced: How do we get new arrivals at SEG15M to stay and assume responsibilities? How do we transform those affected into activists? We began by inverting the line of reasoning by asking not just about why people were leaving SEG15M but also what was being done by the group so that these people did not stay:

The problem is that when people don't participate, we look too much at each other and not enough at what we're doing ourselves. If we don't even know how to hold a meeting and talk about what we need to talk about...What can we demand of a new arrival? To be more than you? It's impossible. We cannot grow by hoping that others come with the desire to make the revolution. [Group A, session 3]

From this diagnosis, we reflected on concrete proposals that would reverse the situation. The first of these dealt with how to improve the reception of newcomers:

The first thing the assembly has to do is to ask how many new cases there are and explain to them how we function; what the assembly consists of and how it will be held. That takes time, but you always have to direct the assembly at the new arrivals. Why? Because those of us there already know how we function. [Group A, session 2]

Beyond the reception phase, there was also the listening to consider:

I also believe that people are not being listened to in the manner they should be listened to. Because many times, new people are not allowed to explain themselves. For them, the first day is like a psychological session. You have to let them at least vent some steam. [Group B, session 4]

We all agreed that if the assemblies were more pleasant and efficient, then the attendance would improve. After which, welcoming new arrivals would take prominence. "Listening, respecting them when they cry, and letting them see that [whoever] speaks to them has gone through something similar" (Marin 2013:3 [trans. AAV, RGS, and AOA]).

The second proposal that emerged in the groups dealt with the initial procedure for new cases. Commonly, a new arrival at a SEG15M assembly is assigned to a support group that will accompany them in solving their situation. However, this assistance 
was not always done correctly. It was being provided as help and not as an empowering opportunity. "First we have to see where the error is. The mistake is that I helped a person and in the way, I helped them..." (Group A, session 3). We realized that the individuals who had stayed the longest in SEG15M were the ones who took the longest to resolve their case. They had struggled a lot and learned. In contrast, those whose cases were quickly resolved ended up leaving. "That paternalism, that assistance that we give them by doing things for them, solving their problem, makes them feel useless. If they don't feel useful, why are they going to stay? What are they going to do here?" (Group B, session 1). A possible solution was to initiate a mentoring practice by older colleagues for newcomers, lasting two or three months. Such close accompaniment would allow the creation of ties, which will help us see the collective in "a different light and my problem in another way. Whether a person stays or leaves, this is not in the assembly, nor in the formation. It is in the treatment we give to each of those we accompany" (Group A, session 2).

The third proposal dealt with the various tasks performed in the collective. For many, SEG15M would become a family, one that endures and always has tasks to do. We reasoned that for the community in which, and for which, it struggles to flourish, each person needed to contribute their knowledge. A principal problem of this was that new arrivals did not know what could be done. Coupled with the sheltering assistance that sometimes occurred, it led to newcomers feeling useless. A female colleague suggested making a list of tasks that could be carried out within the group. By "communicating our interests and strengths, as well as our doubts, we can find the best way to participate in one's interest" (PAH Vellekas 2016:4 [trans. AAV, RGS, and AOA]).
"There are thousands of things and many ways to collaborate, but something should be created to keep him there and for people to know what the tasks are" (Group B, session 2). It was furthered that there should also be a rotation of tasks so as not to rank them:

If at a certain moment, someone important from the collective, one who has been involved the longest, says, "I'll clean with you, I'll sign up!" that elevates it, and it doesn't come across as someone who doesn't know what they're doing. You're honoring it. How do you then tell someone that his work is marvelous if nobody wants it and the same person always does it? [Group B, session 2]

Having analyzed the different aspects of the group participation dynamics, their implications, and meanings for SEG15M, as well as how the 'debate groups' outlined the 'whats' of the research, we shall next reflect on the second crucial element, to communicate.

\section{Communicate: A Bi-Directional Process of Inward and Outward}

One of the collective's main accomplishmentsalong with the rest of the movements' fighting for housing rights-has been to supplant the discourse that blamed the victims for their situations and evictions, telling them that they had "lived beyond their means" (Suárez 2014:85 [trans. AAV, RGS, and $\mathrm{AOA}]$ ), for holding the banks and governments accountable for promoting the housing bubble, over-indebtedness, and for approving unfair laws. This accomplishment has been possible, in part, by its multiple communicative practices. We will focus more on the external communication of SEG15M, noting that the collective's internal communication 
was fundamental and efficient in mobilizing people. Once again, group assemblies are a positive example of spaces where everyone was invited to participate and exchange their knowledge, as well as being instances of active communication.

One of the aspects debated the most during the 'debate groups' had to do with communication between the movement and other social agents. Social communication, the way in which Stop Evictions communicated with society, and in turn, how it viewed and acted towards the collective itself, emerged as one of the main difficulties for the group. "People don't know what SEG15M is, nor how it functions nor how it is...There's very little information outside" (Group C, session 1). However, this was not exclusively a fault of their own. "For a long time, the mortgage drama faced by hundreds of thousands of families didn't resonate in the media to the proportion of the problem" (Colau and Alemany 2012:163 [trans. AAV, RGS, and AOA]). Thousands of families lived silenced and in solitude. It was a drama that did not transcend into the public dialogue, an opaqueness due to unawareness. We shared that for many, before joining the group, SEG15M seemed like a group of "squatters, with nothing else to lose" (Group C, session 1). "Everything with long hair and dog" (Group C, session 1).

To reverse the obscurity, SEG15M began a weekly and public class-action claim against and in front of financial institutions. These demonstrations and mobilizations were established to not only "publicly expose who the culprits were but, above all, to start a process of blamelessness" (Adel et al. 2014:10 [trans. AAV, RGS, and AOA]) for the families who were experiencing evictions, defaults on mortgages or rents, and occupational scenarios.
The 'debate groups' reasoned that although the solutions to the evictions lay in the domain of institutional policy, it was still fundamental to carry out direct public actions. This was an assertion that "the affected cannot sit idly dreaming of new legislation" (Huerga 2015:62 [trans. AAV, RGS, and $\mathrm{AOA}])$. The group's action protests were principally two: the aforementioned public protest against the banking organizations and the halting of evictions. The action of meeting at the bank's door with other affected people was designed to force collective bargaining. It is a tool to put pressure that also "pretends to generate social support by publicly showing the bank's unfair, immoral, and dishonest practices" (Colau and Alemany 2012:203 [trans. AAV, RGS, and AOA]). In some of the debate sessions, it was recognized that due to new arrivals not possessing previous demonstration experience, which at times generated fear or misgivings, the group needed to "encourage people to take actions...we have to awaken that feeling of solidarity because we cannot compel anyone" (Group C, session 4).

The halting of evictions is another demand practice used by the collective. It is an act of civil disobedience by peacefully intervening with people at the door of the affected house, defying court orders. This type of action conforms to the collective's public image, hence, its name. This act of disobedience "shelters itself in a superior jurisdiction, which the Spanish state systematically violates, human rights" (Colau and Alemany 2012:124 [trans. AAV, RGS, and AOA]). We reflected that many people at SEG15M did not know or were unclear on what civil disobedience was and had never thought of practicing it. Moreover, we deliberated on how the perception of civil disobedience still varied after having the option of participating in one. Now, many see it as "a normal practice and as a moral obligation before 
an unjust law" (Mir et al. 2013:58 [trans. AAV, RGS, and $\mathrm{AOA}])$.

Even though SEG15M used these two aforementioned advocacy strategies to give itself visibility, the 'debate groups' countered that it was not enough and that it was necessary to go further to try to occupy both the media and the public space. On the one hand, we needed to appear on the streets in various ways, differently than before, and go beyond the weekly action meetings. "One thing that worked well that I no longer see being done was going to schools and street markets. You talked to people, and it worked...even in the neighborhood squares" (Group B, session 3). Many times, people believe that the collective only focuses on stopping evictions, and it needed to explain that it was more than that, that anyone could join and not just those in need of foreclosure help. Another proposal was:

To commandeer a central spot and start talking with people that this exists [the collective]. Because there are more people than we think who are silenced and don't know what we do...or make a large assembly, each of us with our folding chairs gets together in a central location and conducts our assembly there. Take our megaphone, t-shirts, and make ourselves known. The same that we do here [in the collective], but there. [Group C, session 1]

We also noted the importance of not only demonstrating how SEG15M works but also of showcasing the movement's victories and achievements; the cases in which people solved their housing issues:

One way to attract, and make this attractive is to run a mega marketing campaign... What you have to do here is to make people tell their problems and what steps they took to solve them, with videos in a documentary style. It's important to show that people have solved their own problems. [Group C, session 2]

Another issue deliberated on was the tone in which said actions would be implemented. As a group, we ultimately chose to promote festive strategies, as they were at the start of the collective. It was something that surprised people, considering the pressing issue. More importantly, it attracted newcomers to activism. Dancing, singing, or laughing also helps to "promote an image of the affected that is contrary to that of victims" (Sanz 2017:2 [trans. AAV, RGS, and $\mathrm{AOA}]$ ). Finally, we pointed out that we needed to develop other communicative strategies as entertainment-to create events and fun products that infectiously and subtly engage people alike. "We could do a karaoke at the door of the bank, inviting people to sing with us" (Group C, session 4).

As one can see, the analysis that is done by the group about the forms and needs to communicate more and differently makes it a central key aspect of the operational dynamics of SEG15M. Its emergence, along with the previously analyzed participation, became a topic of great interest in the 'debate groups.' It entailed a decisive element for the collective construction of the research project. At its center were other ways of doing ethnography. Through alternative forms of participating and communicating, different ways of storytelling and conducting research began to take shape. The transmedia project and the radio soap opera were not born in the investigator's work desk but rather emerged from the 'debates groups' where there was a need to communicate and participate differently. This concern also directly questioned those of us who have dedicated ourselves to ethnographic research since we have been reflecting and writing on the need of deploy- 
ing other forms of research. In this perspective, the 'whats' and 'hows' have developed hand in hand.

\section{In Closing. To Participate and to Communicate: Framing the 'Whats' and ‘Hows'}

At the methodological level, to participate and communicate have been the two frameworks on which the entire active listening process is based, as exhibited by the 'debate groups.' Faced with the act of 'grasping' lectures and narratives produced by the 'debate groups,' we became interested in the production of knowledge in all directions and did not just experiment through a specific investigative process but also deploying learning in common with all the various parts involved, from the 'whats' to the 'hows.'

In the dimension of the 'whats' and 'hows' of participating, it has been a collective affirmation of commitment and willingness to be involved against a solitary struggle: to participate, get involved, and commit with the understanding that "being is with the others" (Garcés 2009 [trans. AAV, RGS, and $\mathrm{AOA}]$ ). Communicating was understood as a bidirectional process towards the interior of the group and outwards. Firstly, inward to its less involved and committed members. Secondly, an intragroup communication that is part of the 'debate groups.' Thirdly, to communicate to connect from the SEG15M collective to the city in which the movement takes place, converting themselves into producers and representatives, not consumers of the collective's content. To participate and communicate have emerged as two pillars of the practice of politicizing the suffering (Fernández-Savater 2008; Álvarez Veinguer and Sebastiani 2019), as well as being artifacts of shared construction. A leitmotif of the 'debate groups' bor- rowed from Marina Garcé's (2009 [trans. AAV, RGS, and $\mathrm{AOA}]$ ) series of questions: "How can one be in the world, involving oneself beyond the roles of viewers and consumers? What does it mean to intervene? How to disassociate from being a spectator and actively make the world instead of consuming its objects and experiences?" Further still, "How do you activate civic engagement?" (Garcés 2012 [trans. AAV, RGS, and AOA]).

Returning to our starting point, the 'debate groups' were deployed to collectively define what we wanted to investigate-a collective process within a movement that fights for the right to decent housing; while placing in the center of the questions and objectives of the research, the will to influence, intervene and transform the world we inhabit (Freire 1970; Fals Borda 1986; Santos 2019). All the while, appealing to the ethical-epistemological responsibility of research. The 'whats' were not born as purely intellectual questions, artificially manufactured on the investigator's 'desk work.' They were built in an artisanal way (Santos 2019), slowly and calmly from the group's discomforts and feelings, as enunciated and transmitted in long listening sessions. This process radically transformed the traditional formulation of the 'whats' and the initial investigative queries to meet the demands of the group undergoing a collaborative ethnography. All to leave behind the operational scenario of academic or militant research (Hale 2008).

After this investigative year-long process, we started a transmedia project to abridge the revolving pillars of participation and communication. ${ }^{16}$ We learned to make and produce videos, an image bank and

${ }^{16}$ A creative and collaborative story made up of several others, where anyone can contribute through what they know or want. 
express ourselves in a new visual language while navigating through all the created material. At the methodological level, we deemed it important to deconstruct the academic literature (Santos 2019) and experiment with alternative ways of visually summarizing the collectively-lived experiences (Gray et al. 2020). It was no small feat to stop passively consuming audiovisual products and collectively and collaboratively produce one. We understood that as it had occurred in the 'debate groups,' the politicization of suffering and the processes of political arrangements would require contrasting forms of conducting and presenting research (Álvarez Veinguer and Sebastiani 2019).

The first product was a promotional video encapsulating the movement. ${ }^{17}$ We also produced a video of a 'reporter on the street' asking passerby's opinions and knowledge about evictions, their numbers in Granada and Andalusia, and about the Stop Evictions movements. ${ }^{18}$ In the summer of 2018, we started working on a radio soap opera because we decided to draw on the communal narratives to experiment with other types of registers and uncommon grammars in an academic context (Simon, Bibeau, and Villada 2003). ${ }^{19}$ Following ethnographic fictions as a methodology, it allowed us to construct reality-based narratives, written as a tale or story. This creative product of fiction, that incorporated memory, research, and imagination, has enormous potential because it transforms

\footnotetext{
17 See: https://www.youtube.com/watch?v=9X905BLSYUg\&feature $=$ emb_title.

18 See: https://afectadosporlahipotecagranada.com/reporteros-y-reporteras-stop-desahucios-granada-15m/?fbclid=IwAR2OXkRbdkvM8wkNCTLPH5ubiTM9KhFBtwCbolO0-YM61sxf2EtNS08Azsw.

${ }^{19}$ In June 2018, we organized a course on community narratives within the framework of our project. It was taught by colleagues from the New York team: Angel Luis Lara, professor at SUNY and professional screenwriter, and some colleagues who were producing a radio soap opera in New York on the life experiences of Mexican migrant women in the US.
}

individual experiences into a commonly constructed plot. A fictional account that begins in the first person (' $\mathrm{I}$ '), coupled with the groups' lived experiences, is then transposed to other ways of storytelling, self-reflection, and analysis on each one of the narratives being constructed (LaMarre and Rice 2016).

The radio soap opera, as a means to communicate and participate, is a product that allows us to directly address both pillars at the intra- and inter-group level. Further still, via fiction, it can directly connect the experiences of the affected people with the listeners. For over a year, it has been allowing the building of connections and affections in each of the weekly meetings. This is a type of communal engagement, drawn from stories we like to share. It is a wishful space that exceeds and binds us with what affects the group, from the joy, laughter, and fears, to the creative imaginative moments, politicizing the actions of communication, and participation from shared narratives.

There is no single way of understanding and practicing collaborative ethnography, and in the last decade, several genealogies underline this (Álvarez Veinguer, Arribas, and Dietz 2020). Throughout our co-research process with SEG15M (which began 6 years ago), we have focused our interest on constructing the research in common (the research questions, as well as the methodological approach), adapting ourselves at all times to the group, its characteristics, and its interests. This has implied recognizing other know-how (beyond scientific and expert knowledge) and seeking other ways of incorporating the centrality of the group and the production of knowledge in common. In our case, instead of the individual as the main actor of the research-the central producer of knowledge-we assumed co-research as a horizon that has enabled another way of constructing social 
research. In our experience, this has meant a substantial change in the traditional logic of who formulates the research questions, how the methodology and techniques to be applied are decided since we have tried to decentralize the researcher-to build the process of co-research from the 'debate groups.' This has involved two major changes, as we have been pointing out in this paper: (i) on the one hand, the research questions have not been formulated by the university researcher, but collectively, through a long process of listening through the 'debate groups'; (ii) on the other hand, it has also allowed the building of a solid link between the people who have participated in the process. The work developed since 2018 in the radio soap opera has evidenced a strong commitment and enormous level of responsibility that everyone has assumed and manifested both with the process and with the product, an engagement that we had not been able to detect and perceive in more traditional research experiences. All the people have been linked

\section{References}

AA.VV. 2016. Archivo 15M Granada [15M Granada Archive]. Granada: 15-M de Granada.

Adel, Miquel, Anna Lara, and Elvi Mármol. 2014. “La PAH: origen, evolución y rumbo [The PAH: Origin, Evolution, and Direction]." Anuario de Movimientos Sociales 2013:1-20. Retrieved April 28, 2021 (http://fundacionbetiko.org/wp-content/uploads/2014/02/La-PAH.-Origen-evoluci\%C3\%B3n-y-rumbo.pdf).

Álvarez Veinguer, Aurora and Antonia Olmos Alcaraz. 2020. “Desplegando dispositivos de escucha en una etnografía colaborativa. Los grupos de debate como situaciones instituyentes [Deploying Listening Devices in a Collaborative Ethnography. Discussion Groups as Instituting Situations]." Pp. 113-143 in Investigaciones en movimiento: etnografias colaborativas, feministas y decoloniales [Research in Movement: Collaborative, Feminist, amazingly with something that they have verbalized and felt like their own (not as something foreign and imposed), because it went through them and affected them, and it is being built collectively.

\section{Acknowledgments}

We thank everyone who participated in the project, especially the people from Stop Evictions Granada 15M Movement (SEG15M).

This research received financial support from the project I+D+I "Emerging processes and communal agencies: the praxis of collaborative social research and new forms of political subjectivation," of the State Program for the Promotion of Scientific and Technical Research of Excellence, financed by the Ministry of Economy and Competitiveness of the Spanish Government (Reference: CSO2014-56960-P). The project was finalized in December 2018. and Decolonial Ethnographies], edited by A. Álvarez Veinguer, A. Arribas Lozano, and G. Dietz. Buenos Aires: CLACSO. Retrieved March 29, 2021 (http://biblioteca.clacso.edu.ar/clacso/ se/20201216092831/Investigaciones-en-movimiento.pdf).

Álvarez Veinguer, Aurora and Luca Sebastiani. 2019. “Una década de luchas contra los desahucios. De la vergüenza y la soledad a los agenciamientos cotidianos [A Decade of Struggles against Evictions. From the Shame and Loneliness to Daily Agencements]." Papeles del CEIC 208:1-19. doi: https://doi. org/10.1387/pceic.19502.

Álvarez Veinguer, Aurora and Luca Sebastiani. 2020. “Habitar la investigación en la universidad neoliberal y eurocentrada: la etnografía colaborativa como apuesta por lo común y la subjetivación política [Inhabiting Research in the Neoliberal and 
Eurocentral University: Collaborative Ethnography as a Bet for the Common and Political Subjectivation]." AIBR, Revista Iberiamericana de Antropología 15(2):247-271. doi: http://doi. org/10.11156/aibr.150204.

Álvarez Veinguer, Aurora, Alberto Arribas, and Gunther Dietz. 2020. Investigaciones en movimiento. Etnografías colaborativas, feministas y decoloniales [Research in Movement: Collaborative, Feminist, and Decolonial Ethnographies]. Buenos Aires: CLACSO.

Álvarez, Eva, Patrik Zapata, and María José Zapata. 2014. “Stop the Evictions! The Diffusion of Networked Social Movements and the Emergence of a Hybrid Space: The Case of the Spanish Mortgage Victims Group." Working Paper Series-School of Public Administration (GU). Retrieved April 28, 2021 (http://gup.ub.gu. se/records/fulltext/206630/206630.pdf).

Álvarez Veinguer, Aurora et al. 2016. “Experiencias en construcción: investigación social colaborativa con el colectivo Stop Desahucios 15M Granada y la PAH de Barcelona [Experiences under Construction: Collaborative Social Research with the Collective Stop Desahucios 15M Granada and the PAH of Barcelona]." Congreso Internacional Contested Cities, Madrid.

Arribas, Alberto. 2015. “Antropología colaborativa y movimientos sociales: construyendo ensamblajes virtuosos entre sujetos en proceso [Collaborative Anthropology and Social Movements: Building Virtuous Assemblages between Subjects in Process]." Ankulegi 19:59-73. Retrieved April 28, 2021 (https://aldizkaria. ankulegi.org/index.php/ankulegi/article/view/77/187).

Asociación Pro Derechos Humanos Andaluza [APDHA]. 2019. El $60 \%$ de los desahucios en Andalucía son por impago de alquiler [ $60 \%$ of Evictions in Andalusia Are for Non-Payment of Rent]. Retrieved April 28, 2021 (https://www.apdha.org/60-por-ciento-desahucios-andalucia-impago-alquiler/).

Bertely, María. 2018. “De la antropología convencional a una praxis comprometida [From Conventional Anthropology to Engaged Praxis]." Pp. 225-252 in Prácticas otras de conocimiento(s). Entre crisis, entre guerras [Other Practices of Knowledge(s). Between Crises, between Wars], vol. I, edited by X. Leyva al. Buenos Aires: CLACSO.

Colau, Ada and Adrià Alemany. 2012. Vidas hipotecadas. De la burbuja inmobiliaria al derecho a la vivienda [Mortgaged Lives. From the Real Estate Bubble to the Right to Housing]. Barcelona: Cuadrilátero de libros.

Colau, Ada and Adrià Alemany. 2013. ¡Sí se puede! Crónica de una pequeña gran victoria [Yes We Can! Chronicle of a Small Victory]. Barcelona: Ediciones Destino.
Consejo General del Poder Judicial [CGPJ]. 2019. Datos sobre el efecto de la crisis en los órganos judiciales. Madrid: Consejo General del Poder Judicial [Data on the Effect of the Crisis on Judicial Bodies. Madrid: General Council of the Judiciary]. Retrieved April 28, 2021 (http://www.poderjudicial.es/cgpj/es/Temas/Estadistica-Judicial/Estudios-e-Informes/Efecto-de-la-Crisis-en-los-organos-judiciales/).

Dietz, Gunther and Aurora Álvarez Veinguer. 2014. “Reflexividad, interpretación y colaboración en etnografía: un ejemplo desde la antropología de la educación [Reflexivity, Interpretation, and Collaboration in Ethnography: An Example from the Anthropology of Education]." Pp. 55-89 in La etnografía y el trabajo de campo en las ciencias sociales [Ethnography and Fieldwork in the Social Sciences], edited by C. Oehmichen Bazán. México: UNAM.

Domínguez, Mario and Andrés Dávila. 2008. “La Práctica conversacional del grupo de discusión: jóvenes, ciudadanía y nuevos derechos [The Conversational Practice of the Focus Group: Young People, Citizenship, and New Rights]." Pp. 97-125 in Estrategias y prácticas cualitativas de investigación social [Qualitative Social Research Strategies and Practices], edited by Á. Gordo and A. Serrano. Madrid: Pearson/Prentice Hall.

Fals Borda, Orlando. 1986. Conocimiento y poder popular, lecciones con campesinos de Nicaragua, México y Bogotá [Knowledge and People's Power: Lessons with Peasants in Nicaragua, Mexico, and Colombia]. Bogota: Siglo XXI.

Fernández-Savater, Amador. 2008. "Politizar el sufrimiento [Politicize Suffering]." Minerva 7:111-112.

Freire, Paulo. 1970. Pedagogía de los oprimidos [Pedagogy of the Oppressed]. Mexico: Siglo XXI.

Gaja, Fernando. 2015. “Reparar los impactos de la burbuja constructora [Repairing the Impacts of the Housing Bubble]." Scripta Nova XIX(517):1-37. Retrieved April 28, 2021 (https://revistes. ub.edu/index.php/ScriptaNova/article/view/15121/18324).

Garcés, Marina. 2009. “Un mundo entre nosotros. La fuerza del anonimato [A World among Us. The Power of Anonymity]." Revista Espai en Blanc (5-6). Retrieved April 28, 2021 (http://espaienblanc.net/?page_id=448).

Garcés, Marina. 2012. "Renovar el compromiso [Renewing Commitment]." Revista Espai en Blanc (9-10-11). Retrieved April 28, 2021 (http://espaienblanc.net/?page_id=621).

Gray, Julia et al. 2020. "Knowledge as Embodied, Imaginative, and Foolish Enactment: Exploring Dementia Experiences 
through Theatre." Forum: Qualitative Social Research 21(3):1-21. doi: https://doi.org/10.17169/fqs-21.3.3444.

Greenwood, Davydd. 2008. "Theoretical Research, Applied Research, and Action Research." Pp. 319-340 in Engaging Contradictions: Theory, Politics, and Methods of Activist Scholarship, edited by Ch. Hale. Berkeley, Los Angeles, London: University of California Press.

Gregorio, Carmen. 2019. “Explorar posibilidades y potencialidades de una etnografía feminist [Exploring Possibilities and Potentialities of a Feminist Ethnography]." Disparidades 74(1). doi: https://doi.org/10.3989/dra.2019.01.002.01.

Grosfoguel, Ramón. 2016. “Del 'extractivismo económico' al 'extractivismo epistémico' y al 'extractivismo ontológico': una forma destructiva de conocer, ser y estar en el mundo [From 'Economic Extractivism' to 'Epistemical Extractivism' and 'Ontological Extractivism': A Destructive Way to Know, Be, and Behave in the World]." Tabula Rasa 24:123-143. Retrieved April 28, 2021 (http:// www.revistatabularasa.org/numero-24/06grosfoguel.pdf).

Hale, Charles. 2008. Engaging Contradictions. Theory, Politics, and Methods of Activist Scholarship. Berkeley: University of California Press.

Harding, Sandra. 1993. "Rethinking Standpoint Epistemology: What Is Strong Objectivity?" Pp. 49-82 in Feminist Epistemologies, edited by L. Alcoff and E. Potter. New York: Routledge.

Harvey, David and Neil Smith. 2005. Capital financiero, propiedad inmobiliaria y cultura [Financial Capital, Real Estate, and Culture]. Barcelona: UAB.

Holmes, Douglas and George Marcus. 2008. “Collaboration Today and the Re-Imagination of the Classic Scene of Fieldwork Encounter." Collaborative Anthropologies 1:81-101. Retrieved April 28, 2021 (https://muse.jhu.edu/article/367009/pdf).

Huerga, Carlos. 2015. “Desde V de Vivienda a la PAH, la lucha por el derecho a la vivienda [From V de Vivienda to the PAH, the Fight for the Right to Housing]." Viento Sur 138:57-62. Retrieved April 28, 2021 (https://vientosur.info/IMG/pdf/VS138_C_Huerga_ Desde_V_de_Vivienda_a_la_PAH_la_lucha_por_el_derecho_a_ la_vivienda.pdf).

Ibáñez, Jesús. 1979. Más allá de la sociología. El grupo de discusión: técnica y crítica [Beyond Sociology. The Group Discussion: Technique and Critique]. Madrid: Siglo XXI.

Instituto Nacional Estadística [INE]. 2019. Tasa de riesgo de pobreza por comunidades autónomas [At-Risk-of-Poverty Rate by Au- tonomous Community]. Retrieved April 28, 2021 (https://www. ine.es/jaxiT3/Datos.htm?t=9963\#!tabs-tabla).

Köhler, Axel. 2018. "Acerca de nuestras experiencias de co-teorización [About Our Co-Theorization Experiences]." Pp. 401428 in Prácticas otras de conocimiento(s). Entre crisis, entre guerras [Other Practices of Knowledge(s). Between Crises, between Wars], vol. I, edited by X. Leyva et al. Buenos Aires: CLACSO.

LaMarre, Andrea and Carla Rice. 2016. “Embodying Critical and Corporeal Methodology: Digital Storytelling with Young Women in Eating Disorder Recovery." Forum: Qualitative Social Research 17(2):1-26. doi: https://doi.org/10.17169/fqs-17.2.2474.

Lassiter, Luke. 2004. "Collaborative Ethnography." Anthronotes 25(1):1-16. doi: http://dx.doi.org/10.4135/9781526421036766518.

Lassiter, Luke. 2005. The Chicago Guide to Collaborative Ethnography. Chicago: University of Chicago Press.

Leyva, Xochitl. 2018. “¿Academia versus activismo? Repensarnos desde y para la práctica teórico-política [Academia versus Activism? Rethinking Ourselves from and for Political-Theoretical Practice]." Pp. 199-222 in Prácticas otras de conocimiento(s). Entre crisis, entre guerras. Tomo II [Other Practices of Knowledge(s). Between Crises, between Wars], vol. II, edited by X. Leyva et al. Buenos Aires: CLACSO.

Leyva, Xochitl and Shanon Speed. 2008. “Hacia la investigación descolonizada: nuestra experiencia de co-labor [Towards Decolonized Research: Our Experience of Co-Labor]." Pp. 34-59 in Gobernar (en) la diversidad: experiencias indígenas desde América Latina. Hacia la investigación de co-labor [Governing (in) Diversity: Indigenous Experiences from Latin America. Towards Co-Labor Research], edited by X. Leyva, B. Araceli, and S. Speed. México: CIESAS, FLACSO Ecuador y FLACSO, Guatemala.

Malo, Marta. 2004. “Prólogo [Foreword]." Pp. 13-40 in Nociones comunes. Experiencias y ensayos entre investigación y militancia [Common Notions. Experiences and Essays between Research and Militancy], edited by M. Malo. Madrid: Traficantes de Sueños.

Mangot, Lluís. 2013a. “La PAH. De la Crisis a la Estafa. Del Prozac al Empoderamiento [The PAH. From Crisis to Swindle. From Prozac to Empowerment]." Clivatge 2:56-88. Retrieved April 28, 2021 (https://revistes.ub.edu/index.php/clivatge/article/ view/10021).

Mangot, Lluís. 2013b. “Cronología: burbuja, crisis y PAH [Chronology: Bubble, Crisis, and PAH]." Anuari Del Conflicte Social 3:272283. Retrieved April 28, 2021 (10.1344/test.acs.2013.3.10338). 
Marin, Gloria. 2015. “Organizarnos para cambiar las cosas: qué debemos aprender del feminismo y de la PAH [Organizing to Change Things: What We Should Learn from Feminism and the PAH]." Coordinadora feminista (FEOF). Retrieved April 28, 2021 (http://www.feministas.org/organizarnos-para-cambiar-las.html).

Mir, Jordi et al. 2013. "Fundamentos de la Plataforma de Afectados por la Hipoteca: activismo, asesoramiento colectivo y desobediencia civil no violenta [Fundamentals of the Plataforma de Afectados por la Hipoteca: Activism, Collective Counseling, and Nonviolent Civil Disobedience]." Educación Social 55:52-61. Retrieved April 28, 2021 (https://www.raco.cat/ index.php/EducacioSocial/article/view/271042/368923).

Naredo, José Manuel and Antonia Montiel. 2010. El modelo inmobiliario español y su culminación en el caso valenciano [The Spanish Real Estate Model and Its Culmination in the Valencian Case]. Barcelona: Icaria.

Olmos Alcaraz, Antonia et al. 2018. “Etnografía con los movimientos de lucha por el derecho a la vivienda en el sur de Europa: retos metodológicos en la investigación colaborativa para la acción social [Ethnography of Housing Movements Struggling in Southern Europe: Methodological Challenges in Collaborative Research for Social Action]." Universitas Humanística 86:139-166. doi: 10.11144/Javeriana.uh86.emld.

PAH Vallekas. 2016. “'No estás sola': hablemos sobre la dimensión afectiva de PAH Vallekas ['You Are Not Alone': Let's Talk about the Affective Dimension of PAH Vallekas]." Pah Vallekas. Retrieved April 28, 2021 (http://pah-vallekas.org/no-estas-solahablemos-sobre-la-dimension-afectiva-de-pah-vallekas).

Plataforma de Afectados por la Hipoteca [PAH]. 2019. Una vez cerrado el año 2019, según los datos del CGPJ, hablamos de 250 desahucios al dia [Once the Year 2019 Is Closed, According to CGPJ Data, We Are Talking about 250 Evictions per Day]. Retrieved April 28, 2021 (https://afectadosporlahipoteca.com/2020/03/10/250-desahucios-al-dia/).

Rappaport, Joanne. 2007. Más allá de la escritura: la epistemología de la etnografía en colaboración [Beyond Writing: The Epistemology of Collaborative Anthropology]." Revista Colombiana de Antropología 43:197-229. Retrieved April 28, 2021 (https://www.redalyc.org/pdf/1050/105015277007.pdf).

Rappaport, Joanne. 2008. "Beyond Participant Observation: Collaborative Ethnography as Theoretical Innovation." Collaborative Anthropologies 1:1-31. Retrieved April 28, 2021 (http:// sgpwe.izt.uam.mx/files/users/uami/lauv/Rappaport_Beyon_ Part_Observation.pdf).
Sánchez, Ariana et al. 2017. "La construcción de comunes en la lucha por la vivienda: etnografía colaborativa junto al colectivo Stop Desahucios 15M Granada y la PAH de Barcelona [The Construction of Commonalities in the Struggle for Housing: Collaborative Ethnography with the Collective Stop Desahucios 15M Granadaand the PAH in Barcelona]." Pp. 119-136 in Rebeldías en común. Sobre comunales, nuevos comunes y economías cooperativas [Rebellions in Common. On Commons, New Commons, and Cooperative Economies], edited by O. Abasolo et al. Madrid: Libros de Acción.

Santos, Boaventura de Sousa. 2019. El fin del Imperio Cognitivo. La afirmación de las epistemologías del Sur [The End of the Cognitive Empire. The Coming of Age of Epistemologies of the South]. Madrid: Trotta.

Sanz, Mariona. 2017. “QQué lecciones en comunicación nos puede dar la PAH? [What Lessons in Communication Can the PAH Give Us?]" Otro mundo en marcha. La blogosfera de la plataforma 1015 y más. Retrieved April 28, 2021 (http://www. otromundoestaenmarcha.org/hable-sin-miedo/2015/07/07/quelecciones-en-comunicacion-nos-puede-dar-la-pah/).

Sebastiani, Luca, Borja I. Fernández, and Rocío García. 2016. "Lotte per il diritto alla casa nello Stato spagnolo: la Plataforma de Afectados por la Hipoteca. Campagne, successi e alcune chiavi di riflessione [Struggles for the Right to Housing in the Spanish State: The Plataforma de Afectados por la Hipoteca. Campaigns, Successes, and Some Keys to Reflection]." Interface: A Journal on and for Social Movements 8(2):363-393.

Simon, Sherry, Gilles Bibeau, and Carolina Villada. 2003. “Etnografía y ficción: ficciones de la etnografía [Ethnography and Fiction: Fictions of Ethnography]." Revista de Antropología experimental 16:1-7. Retrieved April 28, 2021. doi: https://doi. org/10.17561/rae.v0i16.3130.

Stop Desahucios Granada 15M [SEG15M]. 2014. Criterios básicos de funcionamiento del grupo Stop Desahucios Granada 15M [Basic Operating Criteria of the Stop Evictions Granada 15M Group]. Retrieved April 28, 2021 (https://afectadosporlahipotecagranada.com/download/documento\%20de\%20funcionamiento/ DOC MENTO\%20FUNCIONAMIENTO\%20STOP\%20DESAHUCIOS.pdf).

Suárez, Maka. 2014. “Movimientos sociales y buen vivir: Ecuatorianos en la lucha por la vivienda en la PAH [Social Movements and Good Living: Ecuadorians in the Struggle for Housing in the PAH]." Revista de Antroplogía Experimental 14:71-89. Retrieved April 28, 2021 (https://revistaselectronicas.ujaen.es/ index.php/rae/article/view/1883/1635). 
Suárez-Krabbe, Julia. 2011. “En la realidad. Hacia metodologías de investigación descoloniales [Within Reality. Towards De-Colonial Research Methodologies]." Tabula rasa 14:183-204. Retrieved April 28, 2021 (http://www.scielo.org.co/pdf/tara/n14/n14a08.pdf).

Vasco, Luis. 2002. “En busca de una vía metodológica propia: replanteamiento del trabajo de campo y la escritura etnográfica [In Search of a Methodological Path of Our Own: Rethinking Fieldwork and Ethnographic Writing]." Pp. 422-486 in Entre la selva y páramo. Viviendo y pensando la lucha india [Between Jungle and Páramo. Living and Thinking the Indian Struggle], edited by L. Vasco. Bogota: ICANH.
Velasco, Honorio and Ángel Díaz de Rada. 2006. La lógica de la investigación etnográfica. Un modelo de trabajo para etnógrafos de Escuela [The Logic of Ethnographic Research. A Working Model for School Ethnographers]. Madrid: Trotta.

Villasante, Tomás. 2007. “Una articulación metodológica: desde textos del Socio-análisis, I(A)P, F. Praxis, Evelyn F. Keller, Boaventura S. Santos, etc. [A Methodological Articulation: from Socio-analytic Texts, Participative Investigation-Action, Philosophy of Praxis, Evelyn F. Keller, Boaventura S. Santos, etc.]." Política y Sociedad 44(1):141-157.

\section{Citation}

Álvarez Veinguer, Aurora, Rocío García Soto, and Antonia Olmos Alcaraz. 2022. "Methodological Experiences in Collaborative Ethnography. Communication and Participation as Frameworks for Constructing in Common." Qualitative Sociology Review 18(1):6-27. Retrieved Month, Year (http://www.qualitativesociologyreview.org/ENG/archive_eng.php). DOI: https://doi. org/10.18778/1733-8077.18.1.01 